\title{
Toughening Behavior in Ceramics and Cermets
}

\section{P. F. Becher. E. Y. Sun. C. H. Hsueh. and K. P. Plucknett" ( ) ak Ridge Vational Laboratory. Oak Ridge. $\mathrm{N}$}

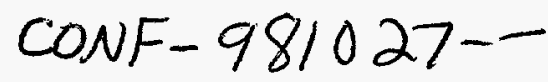

\author{
H. D. Kim
}

Korean Instimle of Machinery and Materials. Changwon. Korea

\author{
K. Hirao and M. Brito \\ Cational Industrial Research Institute. Nagoya. Japan
}

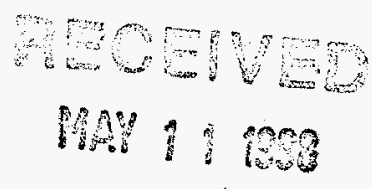

0851

Ke'lnords: Self-reinforced. Silicun nilricie. Vickel Aluminide-bonded. Carbide. Toughness, Strength

\begin{abstract}
The development of high strength $1 \geq 1 \mathrm{GPa}$ ), high toughness ( $\geq 10 \mathrm{MPa}$ m) ceramic systems is being examined using two approaches. In cilicon nitride. toughening is achieved by the introduction of large prismatic shaped grains dispersed in a tine grain matrix. For the system examined herein. both the microstructure and the composition must be controlled. A distinctly bimodal distribution of grain diameters combined with controlled sttria to alumina ratio in additives to promote interfacial debonding is required. U'sing a cermet approach. ductile $\mathrm{Niz} A \mathrm{Al}$-bonded $\mathrm{TiC}$ exhibited toughening due to plastic deformation within the $\mathrm{Ni}$ Al binder phase assisted by interfacial debonding and cleavage of TiC grains. The $\mathrm{TiC}-\mathrm{Ni} \mathrm{Al}_{3} \mathrm{Al}$ cermets have toughness values equal to those of the WC-Co cermets. Furthermore, the $\mathrm{TiC}-\mathrm{Ni}$ Al cermets exhibit high strengths that are retained in air to temperatures of $-1000^{\circ} \mathrm{C}$.
\end{abstract}

\section{Introduction}

In brittle systems. crack wake bridging processes are an important approach to enhance the fracture resistance. Some successful examples include whisker-reinforced ceramics. ${ }^{l}$ self-reinforced silicon nitrides. 2.3 fiber-reinforces ceramics. 4.5 and cermets that combine a ceramic matrix with a ductile metallic or intermetallic phase..$^{0.7}$ In many of these. crack front mechanisms (e.g., crack tip deflection, ${ }^{8}$ microcracking. deformation of a ductile phase ${ }^{5.6}$ ) also contribute to the toughening response. In many cases. it is necessary to design ceramics to have both high toughness and high fracture strength which is the case in the present study. Two systems are considered: the first based on the use of microscopic brittle reinforcements-the self-reinforced silicon nitrides. ${ }^{9}$ and the second based on an intermetallic honding phase in carbides (e.y. Vi. 11 -honded $\mathrm{TiC}^{10}$ ).

\section{Experimental}

\section{Processing}

The processing of the self-reinforced silicon nitride ceramics is based on the seeding method to develop a distinct bimodal distribution of grain sizes consisting of large elongated grains in a fine grained matrix. 11 Details of the processing can be found in refs. 9 and 11 . The $\mathrm{Ni}$ Al-bonded $\mathrm{TiC}$ cermets were fabricated both by pressureless sintering of mixtures of $\mathrm{TiC}$ and $\mathrm{Ni}_{3} \mathrm{Al}$ powders and by melt-infiltration sintering as described in refs. $12 \mathrm{a}$ and $\mathrm{b}$.

\section{Characterization}

The microstructures of dense materials were assessed by optical and scanning electron microscopy. R-curve responses were determined using a precracked applied moment double cantilever beam (AMDCB)

- Invited paper. Engineering Ceramics '98 Conference. Osaka. Japan. Oct. 6-9. 1998

" Vuw with Lnilever Research. Bedtordshire. England

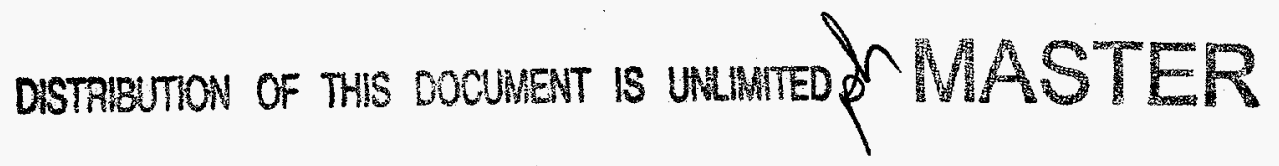

\footnotetext{
"The submitted manuscript has been authorized by a contractor of the U.S. Government under contract No. DE-ACO5960R22464. Accordingly, the U.S. Government retains a nonexclusive, royalty-free license to publish or reproduce the published form of this contribution, or allow others to do so, for U.S. Government purposes."
} 
This report was prepared as an account of work sponsored by an agency of the United States Government. Neither the United States Government nor any agency thereof, nor any of their employees, makes any warranty, express or implied, or assumes any legal liability or responsibility for the accuracy, completeness, or usefulness of any information, apparatus, product, or process disclosed, or represents that its use would not infringe privately owned rights. Reference herein to any specific commercial product, process, or service by trade name, trademark, manufacturer, or otherwise does not necessarily constitute or imply its endorsement, recommendation, or favoring by the United States Government or any agency thereof. The views and opinions of authors expressed herein do not necessarily state or reflect those of the United States Government or any agency thereof. 


\section{DISCLAIMER}

Portions of this document may be illegible in electronic image products. Images are produced from the best available original document. 


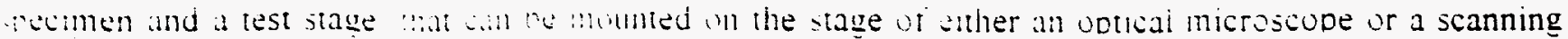
siectron microscope. "a. lla

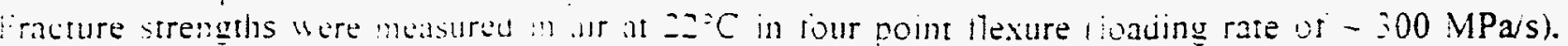

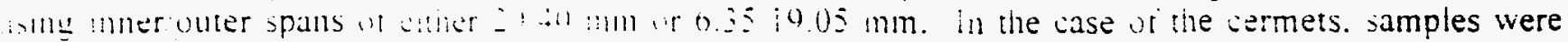

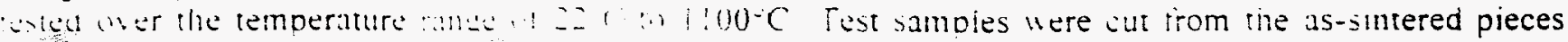
any chectrical discharge malumms an then surtace tinished with diamond abrasive wheels to remove

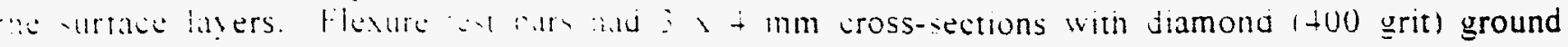

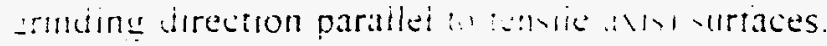

\section{Results and Discussion}

1. Self-Reinforced Silicon Vitride Ceramics

The development of hurer chongated grans in the silicon nitride matrix to gain increases in wughness is well known. Hwweler. it has now been shown that simply generating larger elongated grains is not a sutficient condition: In lact. the uncontroiled development of large elongated grains can be quite derimental. As seen in Figure . . he plateau value of the fracture resistance (or steady-state toughness) $\therefore$ an be rassed over that of a tine aramed equiaxed material with the formation of elongated reinforcing grams. However. only when a distmut bumodal distribution of grain diameters is developed does the ioughening effect begin to he untmized. Figure 2.9 Of equal importance is the fact that the fracture trengths of these same silicon hitrides sinbit a similar trend with the highest strength again achieved in the material with the distinct iraction of larger elongated grains in a very tine grained matrix. Table $I$.
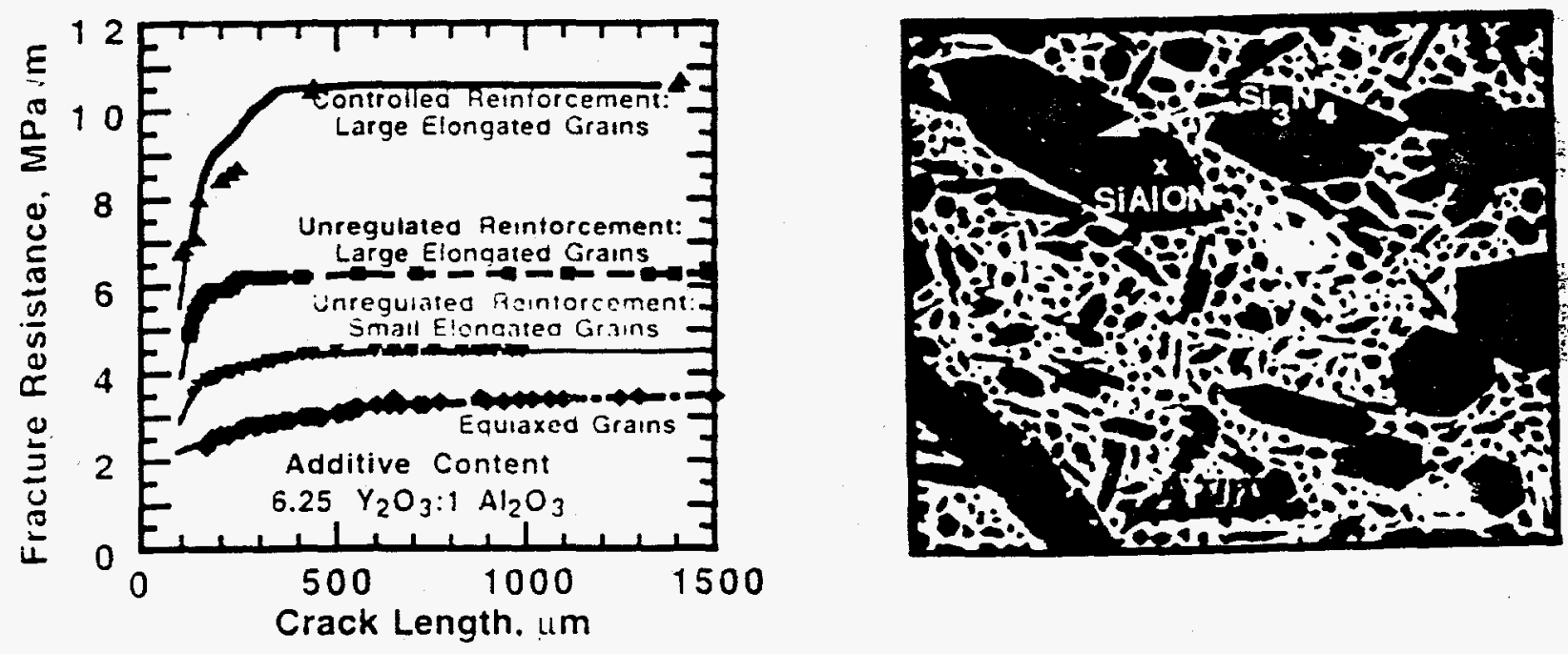

Fieure 1. The formation of a controlted micostructure with larger elongated grams dispersed in a tine grained matrix is used in the Welopment of self-reintorced silicon murides wilh high tracture toughness and strength.

Figure 2. Controlled use of larger $\beta$-seeds in a line matrix powder was used to generate a distinct bimodal microstructure. The growth of an epitaxial SIAION laver on the larger $\beta$-seeds is noted (plasma etched).

The toughening involving crack wake bridging by the elongated grains relies on debonding of the intertace between the grains and the amorphous intergranular phase. Earlier studies of whisker-glass mudel sy stems with alummum is one of the glass constituents revealed that such interfacial debonding is inthenced by the structure and composition of the interface region. 13 . More recent findings indicate that :he intertacial debond strength 11 both the glass-whisker model systems and the self-reinforced silicon alrudes Jecreases as the 11 ind (1) content of the epitaxial SiAlON growth laver on the large elongated yrams decreases. The Al and ()) contents of both the SiAlON growth layer and the intergranular glassy Filase can be controlled by regulating the $\mathrm{Y}_{2} \mathrm{O}_{3}: \mathrm{Al}_{2} \mathrm{O}_{3}$ ratio in the sintering additives. As a result, both the steady-state toughness values. Figure $j$. and the steepness of the initial rising portion of the R-curves 
increased as the $Y$ :Al additive ratio increased in self-reintorced samples having comparable inicrostructures. In-situ observations of irack interactions with microstructures revealed increasing amounts of intertacial debonding and interoranular failure associated with the large elongated $\mathrm{Si}_{3} \mathrm{~N}_{4}$ grains as the Y:Al ratio in the additives increased. In the material with the lowest $Y$ :Al additive ratio. interfacial bonding between the large elongated $\beta-S i{ }_{3} N_{\downarrow}$ grains and the intergranular phase was strong. and most of the larger elongated grains tailed transgranularly.

Table 1. Fracture strength. as well as toughness, is dependent upon control of the microstructure.

\begin{tabular}{|l|c|c|}
\hline $\begin{array}{l}\text { Material: Silicon Nitride Using } 0.25 \mathrm{wt} \% \\
\text { As Sintering Additives }\end{array}$ & 10.5 & Flexure Strength, MPa \\
\hline $\begin{array}{l}\text { Controlled Reinforcement } \\
\text { Large reinforcing grains } \\
\text { Distinct Bimodal Grain Size Distribution }\end{array}$ & 6.5 & 1140 \\
\hline $\begin{array}{l}\text { Unregulated Reinforcement } \\
\text { Larger reinforcing grains } \\
\text { Broad Monomodal Grain Size Distribution }\end{array}$ & 4.5 & 850 \\
\hline $\begin{array}{l}\text { Unregulated Reinforcement } \\
\text { smail reinforcing grains } \\
\text { Broad Monomodal Grain Size Distribution }\end{array}$ & 3.5 & 925 \\
\hline $\begin{array}{l}\text { No Reinforcement } \\
\text { small equiaxed matrix grains }\end{array}$ & 660 \\
\hline
\end{tabular}

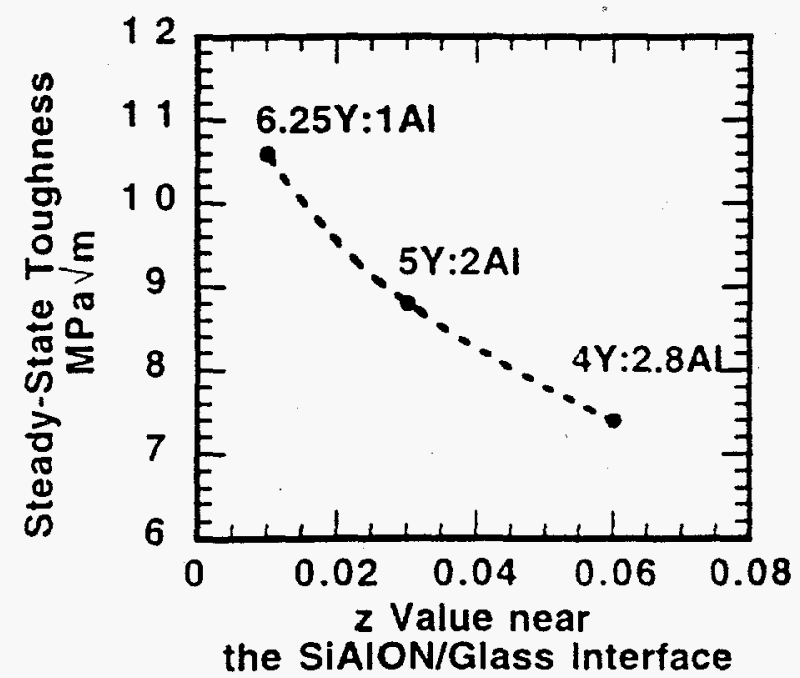

Figure 3. The steady-state (plateau) toughness of self-reinforced silicon nitrides with the same controlled microstructure increases with decrease in $\mathrm{z}$-value ( $\mathrm{Al}$ and $\mathrm{O}$ content) of the epitaxial $\beta-S i 6-z \mathrm{Al}_{2} \mathrm{O}_{2} \mathrm{~N}_{8-z}$ layer in contact ivith the amorphous intergranular phase.

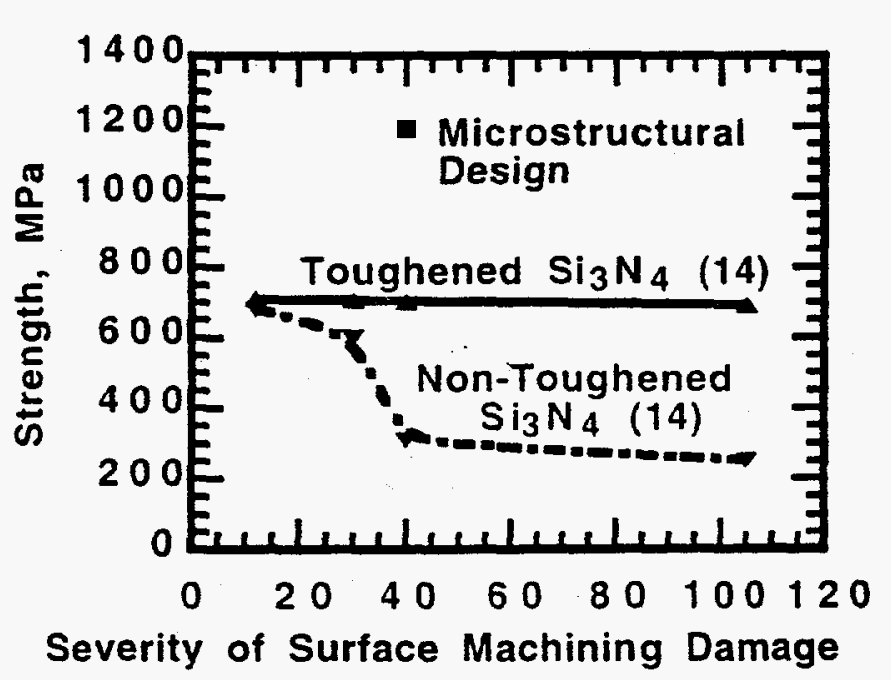

Figure 4. The strengths of silicon nitrides with low toughness degrade with increase in the size of the diamond particles in the surface finishing wheel.

On the other hand, toughened materials are damage resistant. Controlled self-reinforced with controlled microstructures can yield high toughness and strength with damage resistance.

What other benefits might be derived by designing self-reinforced silicon nitrides with controlled Inicrostructures? Earlier studies showed that toughened silicon nitride ceramics can exhibit much greater resistance to strength losses induced by increasingly severe surface machining. ${ }^{14} \mathrm{~A}$ comparison of the response of the present high toughness. high strength silicon nitride with the controlled microstructure to the results of the studies by Tajima and Urashima is shown in Figure 4. Clearly, the use of microstructural 
design that results in the generatsin "t hrger eiongated grains that are "well dispersed in a tine grain matrix offers exciting opportunitles for developing damage tolerant ceramics.

\section{VizAl-Bonded TiC Cermets}

The VisAl-bonded TiC curmets we part of a family of intermetallic-bonded cermets developed recently. ${ }^{10.12 .15}$ The $\mathrm{Viz}$. Al hinder nhase has certain advantages in that it exhibits a reasonably high yield stress that is retained to elevated temperatures. is ductile $1 \sim 50 \%$ plastic deformation prior to failure in polycrystalline samples). and has good oxidation and corrosion resistance. 16.17 In addition. excellent wetting by the alumındes is achieved in a variety of carbides and borides. This and the relatively low melting point of the aluminides $\left(<1400^{\circ} \mathrm{C}\right)$ are quite attractive from the standpoint of component fabrication.

The fracture resistance of the $\mathrm{Vi}$. Hl-bonded TiC cermets rises as the existing short $(<100 \mu \mathrm{m}$ long) cracks are extended with plateau (steady-state) values approaching $14 \mathrm{MPavm}$ achieved to date using the AMDCB geometry. Figure 5 . From these results. it is not clear what the fracture resistance values would be reduced to for much shorter cracks (e.g., $<20 \mu \mathrm{m}$ ). For those compositions where the binder phase is continuous. the location of the ulp of very short cracks (i.e.. in the TiC grain or in the ductile NizAl phase) would influence the fracture resistance for near zero crack lengths. In-situ observations of the crack during loading reveal that interiace debonding and cleavage of the TiC grains accompany the deformation of the $\mathrm{Niz} \mathrm{Al}$ binder in the wake of the crack. Figure 6.

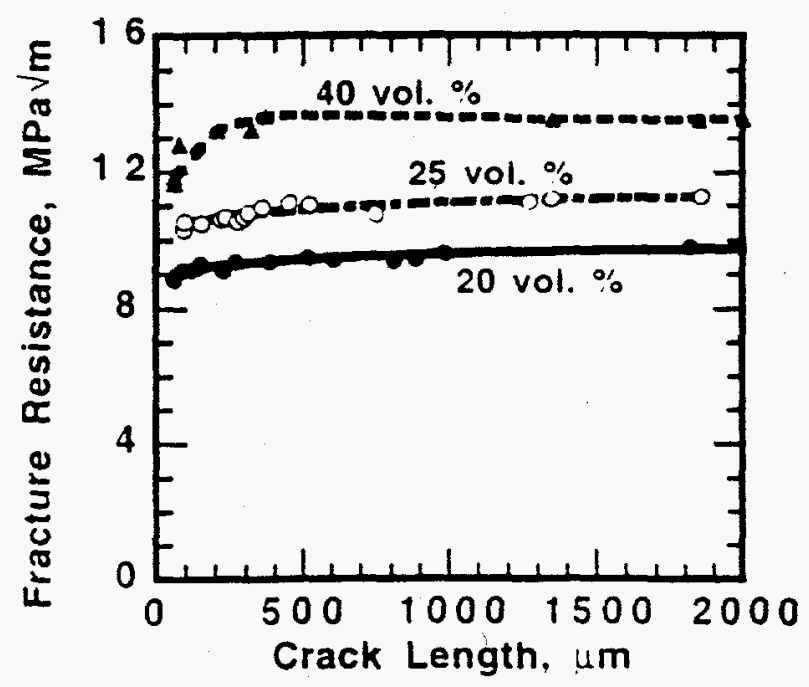

Figure 5 . The fracture resistance increases with crack extension in the $\mathrm{Niz}$. Al-bonded TiC cermets. The toughening effects become greater as the $\mathrm{Ni}$ Al content is raised.

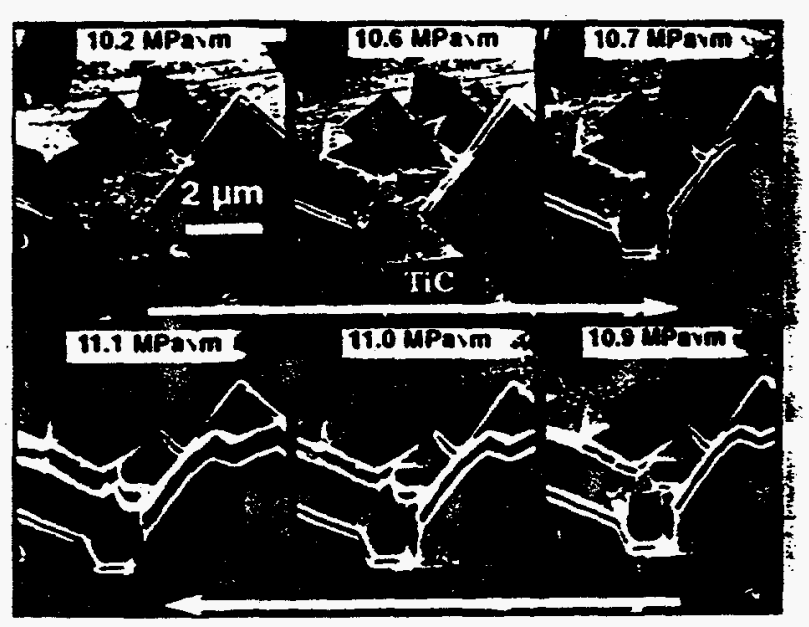

Figure 6. Evidence of deformation of the $\mathrm{Ni}$ Al phase (white bands) and interface debonding plus $\mathrm{TiC}$ fractures is noted as the applied stress intensity increases ( $\mathrm{TiC}-40$ vol. $\% \mathrm{Ni}_{3} \mathrm{Al}$ ).

The steady-state toughness of the $\mathrm{Ni}$ Al-bonded $\mathrm{TiC}$ cermets rivals that of commercial Co-bonded WC cermets and exhibits a similar increase in toughness with amount of the ductile binder phase. Figure 7. (For comparison. measurements of the materials shown in Figures 5 and 7 using the chevron notched beam geometry gave toughness values that were twice the values shown here.) Interface debonding and $\mathrm{TiC}$ eleavage would reduce the triaxial constraint imposed on the binder phase by the rigid TiC structure and. thus. enhance the deformation of the ductile binder phase. The retention of the triaxial constraint would raise the stress for yielding in the $\mathrm{Ni}_{3} \mathrm{Al}$ phase and reduce the toughening contribution of the ductile phase. 6,7 
The potential for these aluminide-bonded cermets in applications over a broad range of temperatures is suggested by the retention of their high flexure strengths to upwards of $1000^{\circ} \mathrm{C}$ in air. Figure 8 . Similar response is noted over a range of $\mathrm{Vi}$ Al-TiC compositions and with other carbide constituents. Macroscopic plastic deformation is wbserved in the cermets at temperatures above $850^{\circ} \mathrm{C}$ in air. This is related to the reduction in the seld point of the $\mathrm{Vi} 3 \mathrm{Al}$ alloys at temperatures above $-00^{\circ} \mathrm{C}$. In the presence of the embedded $\mathrm{TiC}$ rams. global yielding of the ductile $\mathrm{Ni}$ : $\mathrm{Al}$ must be restricted in order to retain the high strengths of the cermets to temperatures approaching $1000^{\circ} \mathrm{C}$. Thus the temperature limit for the cermets may be a tunction of composition.

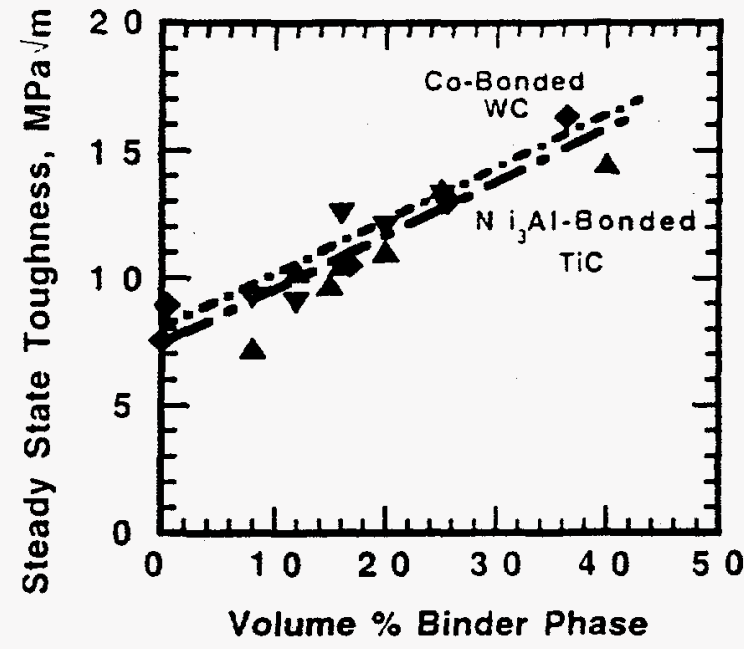

Figure 7. The steady-state toughness of both the $\mathrm{Ni}$ Al-bonded $\mathrm{TiC}$ (filled triangles) and the Co-bonded WC (filled diamonds)are comparable, increasing with ductile binder phase content.

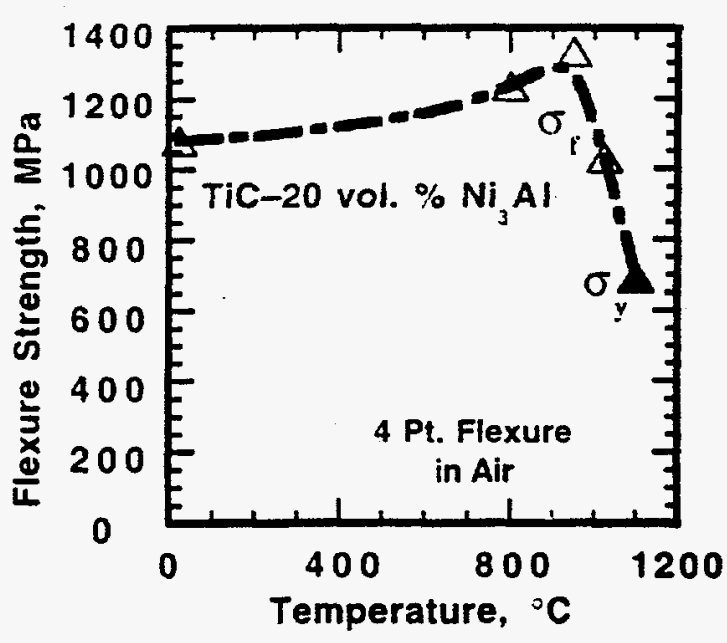

Figure 8. The high fracture strength of the $\mathrm{Ni}_{3} \mathrm{Al}$-bonded $\mathrm{TiC}$ cermet is retained to temperatures approaching $1000^{\circ} \mathrm{C}$ in air.

\section{Summary}

Two approaches are being explored in the development of high toughness ceramic systems that also exhibit high strengths. The tirst employs crack wake bridging by large prismatic shaped grains dispersed in a fine grain matrix as typified by the self-reinforced silicon nitride ceramics. The development of larger elongated grains alone is not sutficient to achieve high strength with high toughness in this system: a distinctly bimodal distribution of grain diameters is required. Debonding of the interface between the larger elongated grains and the amorphous intergranular phase is also necessary to form bridging grains in the crack wake and to initiate deflection of the crack tip. Thus the strength of this interface must be reduced to promote interface debonding over fracture of the large reinforcing grains. With the use of a combination of yttria and alumina additives to promote densification. increasing the $\mathrm{Y}: \mathrm{Al}$ ratio in the additives is shown to enhance intertacial debonding and, hence, the toughness of the self-reinforced silicon nitrides. Combining microstructural control with compositional tailoring can be used to develop high toughness (> $10 \mathrm{MPavm})$ silicon nitride ceramics with high strengths $(>1 \mathrm{GPa})$ and excellent damage resistance.

The second approach incorporates a ductile aluminide (e.g. Ni3 Al) binder phase for carbides (e.g., $\mathrm{TiC})$ and borides to obtain high toughness $(>10 \mathrm{MPa} \vee \mathrm{m})$ and strength $(>1 \mathrm{GPa})$. In this case, debonding of the $\mathrm{TiC}-\mathrm{Ni} \mathrm{Al}_{\mathrm{H}}$ interface and cleavage of the TiC grains accompany plastic deformation within the $\mathrm{Ni} 3 \mathrm{Al}$ binder phase in the crack wake resulting in the increase in toughness. The fracture toughness values of the TiC-NizAl cermets are comparable to those of the WC-Co cermets and increase with ductile binder phase content. In addition. the high strengths of the $\mathrm{TiC}-\mathrm{Ni}_{3} \mathrm{Al}$ cermets are retained in air to temperatures of $-1000^{\circ} \mathrm{C}$ which suggests the potential for a broad range of applications. 
Acknowledgments

The technical assistance of C. G. Westmoreland. S. B. Waters. and T. Geer is gratefully acknowledged. The research was supported by the L. S. Department of Energy, Office of Basic Energy Sciences, Division of Materials Sciences. and Office of Industrial Technologies. Advanced Industrial Materials Program under Contract Vo. DE-AC05-960R22464 with Lockheed Martin Energy Research Corporation.

\section{References}

1. a. P. F. Becher. C. H. Hsueh. K. B. Alexander, and E. Y. Sun, J. Am. Ceram. Soc., 79, 298(1996). b. P. F. Becher, C. H. Hsueh. P. Angelini, and T. N. Tiegs, J. Am. Ceram. Soc. 71, 1050(1988).

2. C. W. Li and J. Yamanis.Ceram. Eng. Sci. Proc.. 10. 632(1989).

3. T. Kavashima, H. Okamoto. H. Yamamoto, and A. Kitamura, J. Ceram. Soc. Japan, 99, 1(1991).

4. A. Kelly and N. H. Macmillan. Strong Solids, Clarendon Press, Oxford, 1986.

5. J. J. Brennan and K. M. Prewo. J. Mater. Sci.. 17, 2371(1982).

6. L. S. Sigl. P. A. Mataga. B. J. Dalgleish. R. M. McMeeking, and A. G. Evans. Acta Metall. 36, 945(1988).

7. V. Kristic and M. Komac. Phil. Mag. A51, 191(1985).

8. E. Y. Sun. C. H. Hsueh. and P. F. Becher. pp. 223-28, in MRS Proc.: Fracture-Instability Dynamics, Scaling and Ductile/Brittle Behavior. Vol. 409 (R. B. Selinger. J. J. Mecholsky, A. E. Carisson, E. R. Fuller Eds., MRS. Pittsburgh. 1996).

9. a. P. F. Becher. E. Y. Sun, K. P. Plucknett, K. B. Alexander, C-H Hsueh, H-T Lin. S. B. Waters, C. G. Westmoreland, E-S Kang, $k$. Hirao, and M. Brito, "Microstructural Design of Silicon Nitride with Improved Fracture Toughness. Part I: Effects of Grain Shape and Size." J. Am. Ceram. Soc., in press.

b. E. Y. Sun, P. F. Becher, C-H Hsueh, S. B. Waters, K. P. Plucknett, K. Hirao, and M. Brito, "Microstructural Design of Silicon Nitride with Improved Fracture Toughness, Part II: Effects of Additives," J. Am. Ceram. Soc., in press.

10. a. K. P. Plucknett. P. F. Becher, and K. B. Alexander, "In-Situ SEM Observations of Fracture Behavior of Titanium Carbide/Nickel Aluminide Composites," J. Microscopy, 185 (2) 206-16 (1997). b. P. F. Becher and K. P. Plucknert, "Properties of NizAl-Bonded TiC," J. Eur. Ceram. Soc., in press.

11. K. Hirao, T. Nagaoka. M. E. Brito, and S. Kanzaki, J. Am. Ceram. Soc. 77, 1857(1994).

12. a. K. P. Plucknett. T. N. Tiegs. P. F. Becher, S. B. Waters, and P. A. Menchhofer, Ceram. Eng. Sci. Proc., 17, 314(1996). b. K.P. Plucknett. P.F. Becher and R. Subramanian, J. Mater. Res., 12, 2515(1997). c. T. N. Tiegs. K. B. Alexander, K. P. Plucknett. P. A. Menchhofer, P. F. Becher, and S. B. Waters, "Ceramic Composites with a Ductile Ni3Al Binder Phase," Mat. Sci. Eng. A209, 243-47 (1996).

13. P. F. Becher, E. Y. Sun. C. H. Hsueh. K. B. Alexander, S. L. Hwang, S. B. Waters, and C. G. Westmoreland. Acta .Metall.. 44. $3881(1996)$.

14. Y. Tajima and K. Urashima. pp. 101-109, in Tailoring of Mechanical Properties of Si3. $\mathrm{N}_{4}$ Ceramics. (M. J. Hoffmann and G. Petzow Eds.. Kluwer Academic Publishers. Dordrecht. Netherlands. 1994).

15. a. R. Subramanian and J. H. Schneibel. JO.M, 49,50(1997). b. R. Subramanian, J. H. Schneibel. K. B. Alexander. and K. P. Plucknett. Scripra Mater., 35, 583(1996).

16. C. T. Liu and D. P. Pope. pp. 17-5. in Intermetallic Compounds: Vol. 2. Practice (J. H. Westbrook and R. L. Fleischer. Eds.. John Wiley \& Sons Ltd.. New York. 1994).

17. V. K. Sikka. pp. 1-119, in Uxidation and Corrosion of Intermetallic Alloys (G. Welsch and P.D. Desai . Eds., Purdue University, West Lafayette, Indiana, 1996). 